Swarthmore College

Works

\title{
The Classroom In The Canon: T. S. Eliot's Modern English Literature Extension Course For Working People And "The Sacred Wood"
}

Rachel Sagner Buurma

Swarthmore College, rbuurma1@swarthmore.edu

L. Heffernan

Follow this and additional works at: https://works.swarthmore.edu/fac-english-lit

Part of the English Language and Literature Commons

Let us know how access to these works benefits you

\section{Recommended Citation}

Rachel Sagner Buurma and L. Heffernan. (2018). "The Classroom In The Canon: T. S. Eliot's Modern English Literature Extension Course For Working People And "The Sacred Wood"'. PMLA. Volume 133, Issue 2. 264-281. DOI: 10.1632/pmla.2018.133.2.264

https://works.swarthmore.edu/fac-english-lit/372

This work is brought to you for free by Swarthmore College Libraries' Works. It has been accepted for inclusion in English Literature Faculty Works by an authorized administrator of Works. For more information, please contact myworks@swarthmore.edu. 


\title{
The Classroom in the Canon: T. S. Eliot's Modern English Literature Extension Course for Working People and The Sacred Wood
}

\author{
RACHEL SAGNER BUURMA AND LAURA HEFFERNAN
}

LAURA HEFFERNAN is associate professor of English at the University of North Florida, and RACHEL SAGNER BUURMA is associate professor of English literature at Swarthmore College. Together, they are writing a disciplinary history of English titled "The Teaching Archive: A New History of Literary Study," which will be published by the University of Chicago Press. Their coauthored work has appeared in Representations, Victorian Studies, and New Literary History.

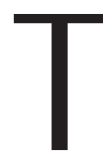

HE STUDY OF ENGLISH LITERATURE HAS THRIVED IN THE CLASSrooms of all kinds of higher education institutions throughout the twentieth century-at university extension programs for working-class students, historically black colleges, main and branch campuses of state universities, small liberal arts colleges, and community colleges. English literature has been core to the curriculum at colonial and postcolonial universities across the globe, and has been taught alongside Native languages and literatures at tribal colleges and universities. Though the vast majority of the study of English literature takes place in classrooms at institutions like these, they have largely been excluded from histories of literary study. ${ }^{1}$

Instead, disciplinary histories of English literary studies almost invariably take the scholarship of a few professors working at a small handful of elite universities as evidence of the main line of the discipline's theories and practices. In doing this, they rely on a mostly unspoken assumption: that the discipline's core methods and texts have been pioneered by scholars at elite universities, only later to "trickle down" to nonelite institutions, teachers, and students. In this kind of account, historicism comes to the American university by way of Johns Hopkins, as does structuralism. New Criticism, on the other hand, begins at Yale, and deconstruction makes landfall there. Scholarship at elite universities sets the method, which is disseminated "outward" to less elite institutions and "downward"-often, disciplinary history imagines, in simplified or distorted form-to the classroom.

Here we make the case that the opposite is true. English classrooms at nonelite institutions have developed groundbreaking approaches to literary study as well as disseminated them; they have significantly shaped the past and present of the discipline in ways

(C) 2018 RACHEL SAGNER BUURMA AND LAURA HEFFERNAN

PMLA 133.2 (2018), published by the Modern Language Association of America 
that are central to everyday experiences of it, if alien to official accounts of its history. ${ }^{2}$ In classes like J. Saunders Redding's African American-centric American literature class at Hampton Institute in the 1940s, Caroline Spurgeon's intensive teaching of literary research methods at Bedford College for Women in the 1910s, and the modern literature seminar T. S. Eliot developed in collaboration with his working-class students at the University of London extension school, students and teachers have come together to study literature in ways that violate both the implicit and explicit tenets of most of the official and informal stories about the discipline. These less elite, far more numerous classrooms have created many central practices and methods, if in ways that are often unacknowledged and uncredited. Turning to these institutions and their classrooms, teachers, and students therefore does more than supplement or diversify existing stories of the discipline of English literary studies; it requires a radical rewriting of them.

\section{The Canon and the Classroom}

Literary historians teach that Eliot almost single-handedly shaped the twentiethcentury literary canon. His dramatic reformation of critical taste, they hold, began with The Sacred Wood. In that 1920 volume of essays, Eliot quietly replaced the major figures of English literature-William Shakespeare, John Milton, John Keats, Alfred Tennysonwith an array of minor Elizabethan and Jacobean playwrights and metaphysical poets and introduced concepts, such as the dissociation of sensibility, that would shape anthologies and literary histories for years to come. E. M. W. Tillyard, for instance, recalls how The Sacred Wood inspired an entire generation of Cambridge students to turn from Romantic, expressive poetry to the metaphysical "poetry of ideas" (98). Stefan Collini credits Eliot with establishing the mid-century's
"'Holy Trinity' of poetry, drama, and the novel" and with effectively decanonizing the Victorian essayists and moralists (16). And critics such as Nicholas McDowell describe how The Sacred Wood's once iconoclastic judgments and assertions came to determine how scholars narrate seventeenth-century literary history. ${ }^{3}$

But it is the principles and methods that underlie Eliot's new canon that scholars feel have most powerfully determined the course of literary study in the twentieth century. As John Crowe Ransom wrote in The New Criticism in 1941, "One of the best things in [Eliot's] influence has been his habit of considering aesthetic effect as independent of religious effect, or moral, or political and social" (138). Indeed, many argue that The Sacred Wood's anti-Romantic canon paved the way for the New Critics' redefinition of literariness as nonexpressive, impersonal, and detached from the immediate circumstances of its composition. ${ }^{4}$ John Guillory, for instance, argues that Eliot's canon reformation-his preference for minor, orthodox poets (John Donne, John Dryden) over major, "heterodox" authors (Shakespeare, Tennyson)-encoded an entirely new set of literary values ("Ideology"). The Sacred Wood, Guillory says, recentered literature's authority on its muteness, its ambiguity, its nonreferentiality-a set of values that English professors reaffirm in the "pedagogical device of close reading" when they attend to the forms of texts rather than to what they say (188). In this sense, Shakespeare, Keats, and Tennyson may remain central to the university literature curriculum, but the way they are taught since Eliot makes them fall in line with the new canon's silent redefinition of literariness. ${ }^{5}$

Yet while imagining that The Sacred Wood determined the texts and practices of countless twentieth-century literature classrooms, scholars have overlooked the actual classroom that made The Sacred Wood. As Ronald Schuchard recounts, Eliot taught 
Modern English Literature, a three-year tutorial course, to working-class adults from 1916 to 1919 (Eliot's Dark Angel 25-51). ${ }^{6}$ The course, offered under the auspices of the University of London Joint Committee for the Promotion of the Higher Education of Working People, met on Monday evenings in Southall at the local grammar school. The students included a "very intelligent grocer who reads Ruskin behind his counter" and several "(female) elementary schoolteachers, who work very hard with large classes of refractory children all day but come with unabated eagerness to get culture in the evening" (Eliot, Letters 168). During their first two years together, the class worked through a collaboratively determined syllabus of nineteenth-century novelists, poets, historians, and social critics. For the third year of the course, Eliot's students requested a year on Elizabethan literature. Eliot obliged, and together they came up with a course that included works by Thomas Kyd, John Lyly, Christopher Marlowe, George Peele, Robert Greene, Shakespeare, John Webster, Ben Jonson, and Francis Beaumont and John Fletcher. In the spring of 1919, Eliot turned his work from the tutorial's third year into a series of book reviews on early modern literature. Six of these reviews would become essays or part of essays in The Sacred Wood.

To reveal how Eliot's Modern English Literature tutorial shaped The Sacred Wood, we reconstruct the social life and institutional contexts for the class. Unlike the two large, lecture-based extension courses Eliot taught in these years-an eleven-week course on modern French literature through the Oxford Extension Delegacy in 1916 and a twenty-five-week course on Victorian literature for the London City Council in 1917Modern English Literature convened a small group of students for three years of intensive, discussion-based study. The course's tutorial format derived from the demands of the Workers' Educational Association (WEA) for collaborative forms of extension educa- tion that would give working-class students a central role in knowledge production and a forum in which to share their unique experiences and knowledge. As Albert Mansbridge, president of the WEA, put it, "The relation of tutor and student in a University Tutorial Class . . . is entirely different from the ordinary relationship of teacher and pupil. The teacher is in real fact a fellow-student, and the fellow-students are teachers" (1). Following the tutorial format, the students of Modern English Literature took a lead role in selecting their tutor, choosing course topics, setting reading lists, determining the amount of time the class spent on each author, and conducting individual research. In his first end-of-year report, Eliot described the class as "experimental and tentative" (qtd. in Schuchard, Eliot's Dark Angel 38). Whereas the audiences for his lecture courses were "extremely intelligent but somewhat passive," he found his tutorial students engaging. As he wrote to his father, "Monday evening is one of the moments of the week that I look forward to. The class is very keen and very appreciative, and very anxious to learn and to think" (Letters 177).

The materials that remain from Modern English Literature show that Eliot was anxious to learn as well. Eliot's syllabi, lecturer's reports, letters, and notes provide a record of how he adapted his teaching to the tutorial form and to the WEA's ethos of equal exchange. Over the course's three years, Eliot revised his syllabi in response to his students' interests and requests and to the pace of their work schedules. These accommodations required significant structural adjustments: jettisoning the format of his first-year syllabus, which moved chronologically through disconnected studies of representative authors, Eliot offered instead a densely interconnected syllabus that foregrounded the material, collaborative working conditions of past writers. As he explained in his reports, this new organization served the practical purpose of 
encouraging his busy students to pursue sustained research with the confidence that their work would remain relevant to class discussion over the course of several weeks. Like other WEA tutors, Eliot learned how to shift the gravity of his course so that Modern English Literature approximated a collaborative exchange rather than a dissemination of culture or knowledge.

As Modern English Literature became more and more collaborative, the class developed a vision of literary history that placed workers at its center. The class's movement away from a syllabus of solitary geniuses to a syllabus peopled by men and women who used source texts, wrote for audiences, adopted influences, manipulated conventions, and collaborated with peers reflects not only Eliot's pedagogical strategizing but also the class's burgeoning literary valuesspecifically, their valuation of authorship as work. Returning to the material practices of writing-newly revealed as collaborative, imitative, repetitive, sometimes paid or patronized-allowed Eliot and his workingclass students to draw connections between the tutorial course's own sociality and the social lives and working practices of the writers they studied. Together, the class came to prize workaday writers like John Ruskin and Dryden-writers whose uneven work became valuable not for its formal perfection but for the way it enabled the future work of other writers. This model of literary value as continued, collective work-made in Eliot's classroom and enshrined in The Sacred Wood-derives, we argue, from the WEA. When we set the three years' worth of materials from Modern English Literature in the context of other WEA extension tutorials offered in these same years, the influence of that tutorial on both the thematic concerns and the literary values of The Sacred Wood snaps into focus.

Our ability to reconstruct the effects that Eliot's extension tutorial had on The Sacred
Wood-and thus on some of the discipline's core theoretical conceptions-depends on the University of London's preservation of the syllabi, course descriptions, lecturer's reports, and graded assignments of courses taught under the authority of the Joint Committee for the Promotion of the Higher Education for Working People. The survival of so many of these documents is unusual. More often, teaching materials are archived only by accident and are cataloged in less detail than the evidence of published scholarship, particularly at less-elite institutions with fewer resources to spend on archival processing. And even when these materials exist, they are often ignored by disciplinary historians. As Jonathan Rose and Alexandra Lawrie have argued, historians of education as well as major disciplinary historians of English like Terry Eagleton and Chris Baldick have caricatured extension schools as simple ideological state apparatuses without examining archival evidence for what happened in their classrooms. ${ }^{7}$ Rose's reconstruction of extension students' experiences in The Intellectual Life of the British Working Classes and Lawrie's work on extension syllabi from the 1890s in The Beginnings of University English have begun to offer an account of the daily life of these classes that moves away from flattening questions of whether they liberated or subjugated working-class students.

Recovering the actual history of teaching is more necessary now than ever. Allor-nothing fantasies about university classroom teaching as revolutionary or reproductive abound, both in stories of the past and in crisis narratives about the present. The study of archival evidence of the teaching of literature can help revise not only the past of literary study but also its possible futures. Returning the submerged but influential history of teaching to the discipline's conversation about itself is essential for taking the full measure of literary study's reach and impact. 


\section{Extension Education and the Tutorial Course}

Before we can reconstruct how Eliot and his students read Elizabethan literature in the year before The Sacred Wood appeared, we must first describe how the ethos and practices of working-class extension education shaped Eliot's teaching. By the time Eliot began teaching extension education courses in 1916, the university extension movement in England was more than forty years old, with an established if flexible set of conventions for convening and running courses in local centers around the country. From its midnineteenth-century beginnings, university extension developed through partnerships among local centers, workers' groups, religious organizations, charismatic individuals, city boards, and university bodies. As Lawrence Goldman writes, the movement "has no easy and obvious delineations, no clear and unambiguous margins; it spills across educational and institutional boundaries" (Dons 5).

Though extension schools worked in concert with many universities, in the early twentieth century the extension movement positioned itself as fundamentally at odds with the university as an institution. Parent universities may have considered their extension programs peripheral, but the WEA countered that extension school students made major contributions to the production of knowledge. It further argued that $\mathrm{Ox}$ ford and the University of London needed working-class students as much as or more than working-class students needed them. John Burrows, in his history of adult education at the University of London, offers an anecdote that captures the disagreement: when the WEA president, Mansbridge, challenged the assumption that extension students enrolled to receive knowledge, R. B. Haldane, chairman of the Royal Commission on University Education in London, asked pedagogically, "Well, of course, a university is a body that imparts knowledge?" Mansbridge replied, "And may I venture to say that it receives itstudents [from tutorial classes] may go right beyond the university degree, dealing with first class research" (qtd. in Burrows 38). ${ }^{8}$ Indeed, the WEA maintained that only through an "education devised by working men in company with scholars" would the disciplines produce a usable account of England's national past and future (Mansbridge 83-84).

The WEA thus rejected the idea that extension courses merely disseminated existing knowledge downward. It also suggested that the collective social relations of knowledge production in the extension school were as important as the knowledge produced. "Tutorial classes," Mansbridge wrote, "are less than nothing if they concern themselves merely with the acquisition or dissemination of knowledge. They are in reality concerned with the complete development of those who compose them, and indeed of the common life" (9). ${ }^{9}$ Such collective ideals were shared by the first wave of tutorial students, who explicitly rejected the proposed model whereby the most talented among them would receive prizes and admission to parent universities (Goldman, "First Students" 51-52). Whereas parent universities saw university extension as a "ladder" that individual students might climb, rung by rung, into the upper regions of the university proper, the WEA argued that universities and their extension programs together already formed a "highway of education" - a broad path linking several locations by which one could reach a variety of destinations (qtd. in Burrows 39). ${ }^{10}$

The classroom archive verifies these two hallmarks of the extension tutorials: a deeply collaborative ethos and a nonsystematic curriculum that positioned working adults as coparticipants in the discovery of unrecorded knowledge. Records show that before the tutor even set foot in the classroom, tutorials were convened through a process of negotiation: tutors offered a list of proposed 
courses, and the students at a local center would choose a topic. The extension delegacy would compare the tutors' offerings with the interests submitted by students and offer a tutor to a group of students for approval. Tutor and students then spent their weeks and months together reading a subject that they had collaboratively chosen. The contingent arrangement of tutorial topics was not merely a convenient mechanism; it was an expression of core extension school values that mandated social relations and students' interests, not a fixed topic imposed by a tutor or institution, should lead the formation of a tutorial.

Extension organizations published syllabi for the chosen classes through their associated university's press. More public than teaching documents are usually imagined to be, these printed syllabi acted as advertisements to potential students, guides to enrolled ones, and records designed to inform the wider public about the extension school's work. They were also part of an important archive, annually bound into volumes that helped record the extension school's history. But despite their printed form, extension school syllabi were flexible documents, responsive to the changing needs of the class and to the necessary indeterminacy of the twenty-four-week lecture series or the threeyear tutorial. For extension students not only collaborated with teachers to determine curricula and course offerings; they also helped create reading lists and weekly topics.

Extension school syllabi often draw attention to their own contingency. The headnote to Alice Davies's 1913-14 syllabus for Some Writers of the Nineteenth Century and After explains that the lectures make "no attempt to deal fully with any of the three periods treated. The subjects have been chosen by the students and tutors jointly, purely on the basis of their inclinations" (3). The syllabus for B. L. K. Henderson's tutorial Aspects of Victorian Literature (1919-21) remarks that after the first year, "the class will be in a posi- tion to discuss whether it wishes to go further into the treasury of the same period, to ascertain the relationship of Victorian writers to those of an earlier period, or to those who have followed in their footsteps" (3). Mabel Atkinson's syllabus for Social History of England (1911-12) notes that her course's method of combining industrial history with economic theory was developed in response to her students, who "desired to study the economic development of England from 1760 and at the same time wished to acquire the elements of economic history" (3).

Flexibility around course topics was possible because, unlike traditional university courses, extension classes eschewed a regularized, hierarchical curriculum in favor of topics of contemporary relevance or student interest. Industrial and economic history courses were common, as were courses exploring the present state of the working class, such as Gilbert Slater's The Worker and the State or J. Lionel Tayler's The Condition of the People. Courses also reflected the current interests of tutors; reading lists featured recent publications like Maria Montessori's The Montessori Method (1912), W. E. B. Du Bois's The Souls of Black Folk (1903), Emilia Kanthack's The Preservation of Infant Life (1907), Beckles Willson's The Story of Rapid Transit (1903), and C. S. Myers's A Text-book of Experimental Psychology (1909). Syllabi reveal how tutors incorporated new knowledge into their syllabi; M. Epstein, who taught his Descriptive Economics tutorial several times in the 1910 s, added new lectures (such as "The Cash Nexus") in response to theoretical developments or student demands ("Syllabus ... Descriptive Economics" [1912], "Syllabus . . . Descriptive Economics" [1915], "Syllabus ... Twenty Lectures"). During World War I, many courses sprang up to cover aspects of the conflict, including R. H. U. Bloor's Ideals and Issues of the Present Struggle (1917), Mabel Palmer's Problems of Social Economics Arising from the War (1916), Mordaunt Shairp's The Literary 
Inspiration of the Great War (1919), and Arnold Freeman's The Economic Problems of Demobilisation (1916), which Freeman taught at Southall, down the hall from Eliot's Modern English Literature.

Extension courses also invited students to create knowledge and incorporated various kinds of research-based classwork. Historians of extension education tend to focus on data about the small proportion of tutorial students who completed the fortnightly papers required to receive course credit. But extension school syllabi indicate a much wider range of student work never documented by institutional record keeping, from fieldwork to oral presentations to at-home experiments to archival research. S. S. Brierley's 1917-18 psychology course asked students "to keep note-books for practical work, in which will be recorded both the experiments performed in class and those carried out at home." Caroline Spurgeon took her Age of Johnson students to the British Museum to conduct original manuscript research. In her lecturer's report, Spurgeon explains that the "system is not that of lectures + paperwork, but the more advanced one of close individual research on the parts of each student in a comparatively limited field." Tayler's course Life in the Home taught students "[h]ow to keep a life-album" on the model of Francis Galton (2). In Poverty: Suggested Causes and Remedies, the first year of R. P. Farley's three-year tutorial in sociology that began in 1911, students made "visits of observation" designed "to bring the members of the class into actual touch with the problems discussed and with various methods of dealing with them" (1). E. H. Pringle's course Modern Economic Problems, offered in 1911, included student presentations on farming, "investment of trade union funds," and the minimum wage that drew on personal experience as the beginning of research (1).

In many cases, extension courses advanced directly to firsthand research and in- dependent study in acknowledgment-rather than willful ignorance-of students' busy work lives. In his lecturer's report for The Life of the Nineteenth Century as Represented in Literature (1914), A. A. Jack describes the "attemptive atmosphere" of his class, in which "everyone was trying to get something out of it and to make use of what was being put before them." His "chiefly poor" students, Jack wrote, "take much interest, work with energy in their spare time, and made very marked progress," quickly coming to "strongly express their desire to have more detailed study of particular authors." Like Jack, Eliot encouraged his students to proceed directly to deep reading precisely because their work lives often prevented them from keeping up with the syllabus. In his lecturer's report for the first year of Modern English Literature, Eliot wrote, "I ask the students all to read some particular work on the current author, in order that there may always be a common basis for discussion; but when (as is usually the case), a student has very little time, I recommend further reading of one author in whom the student is interested, rather than a smattering of all" (qtd. in Schuchard, Eliot's Dark Angel 37). Eliot's dismissal of the kind of class that would offer students a uniform "smattering” of culture echoes extension education's promise to critique and expand disciplinary knowledge rather than simply transmit it.

These untallied instances of researchbased classwork point toward the WEA's internal standards for judging the effectiveness of its courses. Distinct from parent universities' bureaucratic attention to the quantity and quality of papers submitted by creditearning students, the WEA measured the success or failure of a university extension course by the collective life that the course engendered. Mansbridge describes the range of social formations that emerged in parallel to the tutorials: gatherings of students' families and friends, preparatory seminars to keep potential future students up to speed 
while they waited for a course opening, essay circles, and weekend study groups. And there were many senses in which tutorials might "carry on their work beyond the three years" formally allotted to them (43). Extension boards and delegacies tracked how many students went on to write for local newspapers or take further courses; they recorded how many tutorials kept their original composition and moved on as a group to a new subject (Rose 276). In some cases, students extended the life of the tutorial by becoming (unpaid) tutors themselves. The members of a tutorial at Longton, Industrial History of England, traveled to surrounding villages to teach the material to new groups of working people; a group of Yorkshire manual workers finished their tutorial and commenced teaching short courses; tutorial students in North Staffordshire began their own local education program. Though the term "extension education" came from the idea of extending the central research university's mission outward to reach "the people," in practice the idea of the "extension" of knowledge through collective social life came to characterize the work and study of the students themselves.

Turning to Eliot's Modern English Literature syllabi, we show how the values of the WEA tutorial transformed his teaching over the course of the class's three years. Eliot's pedagogy - his shift to an emphasis on self-guided research, his willingness to revise readings and assignments to follow his students' interests, and his focus on creating conditions that enabled his students to have a sustained investment in course topics in the second and third years of the coursetestify to his absorption of the WEA's tested practices and general ethos. These practices also increasingly informed the vision of literary culture Eliot developed in his tutorial and in his writing. Drawing on historicist approaches to literature that emphasized the interconnections between writers, Eliot taught his students to recognize the every- day working conditions under which authors wrote; together, the class developed an idea of literature as a collective cultural enterprise rather than a series of great works by great figures. By importing the WEA's values into the scenes of literary study in this way, Eliot helped his students recognize themselves in the working writers of the literary past.

\section{Modern English Literature, 1916-19}

Like the leaders of the extension movement, Eliot had a vexed relationship to the modern research university. In August 1916, just a month before he began teaching his first two extension courses, Eliot elected not to return to Harvard to take up an assistant professorship. Gail McDonald imagines how difficult this decision must have been for Eliot, given his family's multigenerational devotion to education (3). But entering the world of British extension education let him reject the American system of formal education and the life scripted for him within it while joining an educational institution of a very different kind. The first in a series of dissenting institutions Eliot affiliated with over the course of his career, the extension school allowed Eliot to act as a source of culture for schoolteachers, copy clerks, and the occasional grocer while occupying a position at once marginal and central-marginal to the world of the Oxford or Cambridge common room but central to the extension school movement's reimagination of the national system of higher education.

Eliot's syllabi for his three-year Modern English Literature tutorial contain traces of his course's adaptation to his students' interests, everyday lives, and learning styles. While the first year focused on a series of Victorian authors in the style of the accustomed university literature survey class, the headnote to the syllabus explains that the course is "organized by topic rather than by lecture," giving the class flexibility to linger on some authors and skim over others, rather than binding a given 
author to a particular week (3). After covering Tennyson, Robert Browning, Thomas Carlyle, John Henry Newman, Charles Dickens, William Makepeace Thackeray, George Eliot, Matthew Arnold, minor novelists (Benjamin Disraeli, Thomas Love Peacock, Charles Reade, and Anthony Trollope), the three Brontë sisters, and George Borrow, the tutorial moved on to Ruskin and there remained, giving up the syllabus's final weeks on Edward Fitzgerald and George Meredith to linger with Ruskin, taking time to consider him both as a "stylist" and a "social and moral reformer" (5). It seems likely that these weeks on Ruskin would have drawn on Eliot's students' work experiences and worldviews; their decision to forgo the planned final weeks on Fitzgerald and Meredith shows how the students decided together as a class what they valued and thus how they would spend their time.

The second year's syllabus even more clearly reflects the needs and interests of Eliot's students, who asked Eliot if they could "start with Emerson," which they did, in a course that otherwise exclusively covered British literature of the late nineteenth century (Eliot, Letters 216). After Ralph Waldo Emerson, the class moved to William Morris, Dante Gabriel Rossetti, Algernon Charles Swinburne, Walter Pater, Samuel Butler, and Robert Louis Stevenson and then closed with "The 'Nineties,"” Thomas Hardy, and a concluding week comparing "the later part of the nineteenth century with the earlier" (6). As this list suggests, the scope of the second-year syllabus had been reduced: it contains only nine authors or topics, as compared with the fifteen that Eliot proposed for the first year. This syllabus is also more interconnected: Morris, Pater, and Rossetti are all considered in relation to Ruskin, and Swinburne in relation to the preceding figures. Eliot's lecturer's reports indicate that he was emphasizing connections among these authors to enable students to write more papers. After a first year in which only three students had completed papers, Eliot thought that he might reorganize the course around "subjects" rather than individual authors:

I do not wish to slight the personal element, but if the course can be arranged on the basis of subjects-instead of passing from one man to another, I think more papers would be written; as the members are deterred by thinking that before they can read a book and write about it, the author will have been dropped.

(qtd. in Schuchard, Eliot's Dark Angel 38)

Eliot also included a list of potential paper topics at the end of the second-year syllabus, including "Emerson and His Circle," "Socialism in Literature," "Art for Art's Sake," "Medieval Influence in Poetry and Prose," "Naturalism," "The Celtic Revival," and "The Drama." At the head of this list of paper topics, Eliot promises that these "subjects will be proposed in connection with each lecture" so that students can "plan three or more papers on related subjects" (8).

Over the course of the first two years of Modern English Literature, then, Eliot began to imagine a tutorial in which interconnected subjects replaced authors. His third-year syllabus on Elizabethan literature turned this corner. Structured around the cultural histories, collaborations, and literary forms that reveal the connections among authors, the third-year Modern English Literature syllabus entirely forgoes the movement from "one man to another" in favor of reanimating a literary culture in which Elizabethan dramatists emerge as working writers for the audience of Eliot's working-class students.

This reimagining of the canon of early modern literature as a kind of writers' workshop seems like an inspired bit of teaching, but it was also the practical response to the impasse at which Eliot and his students arrived at the end of their second year together. The first two years' syllabi had proceeded chronologically through nineteenth-century British literature, and the students seem to 
have expected that the third year's syllabus would cover contemporary literature. Eliot, however, did "not favour" the study of "living authors" (qtd. in Schuchard, Eliot's Dark Angel 38). When his students requested a year on Elizabethan literature as their second choice, Eliot happily acceded. What excited him most about the prospect, he explained to his mother, was the opportunity to revalue a literature that had been continuously respected but never "properly criticised": "My Southall people want to do Elizabethan Literature next year which would interest me more than what we have done before, and would be of some use to me too, as I want to write some essays on the dramatists, who have never been properly criticised" (Letters 263). These essays eventually became part of The Sacred Wood.

The Sacred Wood's central exhortation is to rescue works that have been more esteemed than read; instead of approaching them in a "canonical spirit," Eliot urges readers to recover their "living force" (10). Behind The Sacred Wood's revaluation of Elizabethan literature (especially the dramatists) is the work of the third year of Modern English Literature, in which Eliot taught Elizabethan literature in place of and as contemporary literature. The picture of the Elizabethans as "living authors" that Eliot invented in response to the desires of his extension school students became the foundation of The Sacred Wood's imagination of Elizabethan literature.

For Eliot, historical facts could reanimate dead literature. When he later looked back on his years of extension teaching in "The Function of Criticism," Eliot remembered the methods he used to help his students criticize early modern drama. In particular, he emphasized how historical information could lead students to the "right liking" of bygone literature. If he presented students "with a selection of the simpler kind of facts about a work-its conditions, its setting, its genesis," Eliot noted, Elizabethan drama could come to seem as immediate as a recently published poem (20). The Sacred Wood likewise emphasizes the role of historical knowledge in evaluation. In his essay "Euripides and Professor Murray," for instance, Eliot describes how recent anthropological scholarship, by making the past "as present to us as the present," allows readers to form fresh critical opinions about long-dead authors: "If Pindar bores us, we admit it; we are not certain that Sappho was very much greater than Catullus; we hold various opinions about Vergil; and we think more highly of Petronius than our grandfathers did" (Sacred Wood 68).

Eliot may have recalled his role in the extension classroom as that of guide presenting facts to his students, but his letters from the extension years suggest that the biographical and historical information with which he peppered his lectures sometimes put him on unnervingly equal footing with his students. In 1917, while he was teaching Modern English Literature at Southall and lecturing on Victorian literature at Sydenham through the London City Council, Eliot wrote a selfdeprecating letter home about his newfound talent for assembling the sorts of "superficial information" about authors that his students already had:

Lately I have been at a point in my lectures where the material was unfamiliar to me: I have had to get up the Brontës for one course and Stevenson for the other. Of course I have developed a knack of acquiring superficial information at short notice, and they think me a prodigy of information. But some of the old ladies are extraordinarily learned, and know all sorts of things about the private life of worthies, where they went to school, and why their elder brother failed in business, which I have never bothered my head about. (Letters 249)

Here, Eliot's students augment his hastily gathered facts with the kind of tidbits one might cull from late-Victorian-style literary gossip columns and journalistic lives of authors. Tutor and students volley bits of 
information-rapidly collected from several sources, cut adrift from a body of ordered knowledge-that are typically circulated among those who have difficulty judging what is worth putting and keeping in one's head. Yet, in tutorial, these "simpler kinds of facts" do not mark the absence of critical judgment; instead, they become a preparation for it, helping convert authors from revered figures of the English literary tradition into knowable, everyday writers whose lives and times can be discovered in local libraries, or even in the kinds of superannuated periodicals one might find in a coffeehouse or railway waiting room.

Eliot's liberal use in lectures of authorial biography, scenes of writing, composition techniques, and the critical chatter that amounts to literary reputation not only drew on the kinds of knowledge his students already possessed but also reached out to students by moving the focus from the forbiddingly aura-laden work to the more familiar worker. In the third-year syllabus for Modern English Literature (fig. 1), Eliot reconstructed the world in which poets and playwrights wrote, surrounded by their varied source materials, collaborators, influences, and workaday pressures. Eliot designed the first weeks of the syllabus to conjure up the Elizabethan playwrights' world, starting with popular festival and religious rite as the earliest forms of drama, followed by a section on the classical tradition and other influences on drama. Another early unit takes up the material world of the Elizabethan stage. In it, Eliot and his students covered stage construction, audience demands, and the playwright's "continuous adaptation of old plays to current needs" (1). Reading G. P. Baker's The Development of Shakespeare as a Dramatist (1907) set the scene for the collaborative working life of Elizabethan dramatists and offered a frame for thinking about Shakespeare as of his time.

After these opening weeks on the source material and social life of Elizabethan drama, the class moved on to a set of densely inter- connected weeks on Elizabethan playwrights, taking up several playwrights each week to trace influences, compare different examples of a single genre, and view collaborations. The class read Kyd's Spanish Tragedy alongside Titus Andronicus and Hamlet to compare different examples of the tragedy of blood and to contrast treatments of stock situations. They studied Greene and Peele alongside Marlowe, as playwrights influenced by Marlowe's style. In a week on the chronicle play, the class read The True Tragedy of Richard the Duke of York with Richard III and Henry VI to glimpse the "traces of Marlowe, Peele, Greene, and Shakespeare" in that unattributed play (3). From a first year dominated by single author figures to a final year that seeks connections among authors in the material contexts of their world, Eliot's syllabi demonstrate his development of an approach to teaching literary history that demystified great authors to make space for his students' own research.

The critical judgments that anchor The Sacred Wood fully emerge in the final weeks of the third-year syllabus. Eliot's descriptions under each heading become lengthier and the language becomes noticeably evaluative: "greatest," "highest point," "beauty," "greatness" (7). These markers of highest praise are awarded not to Shakespeare but to Jonson, to George Chapman, to Thomas Dekker, to Thomas Heywood, to Thomas Middleton, to Beaumont and Fletcher, and to Webster. Yet even in this turn from historical inquiry to evaluation, Eliot de-emphasizes the final, polished literary work and the singular author. The greatness of these lesser-known writers can be found, for Eliot, in the scene rather than in the complete play; it is fully realized only in the collective literary culture, not in any individual. Despite the fact that "the greatest of Shakespeare's followers is undoubtedly John Webster," Webster's greatness is skill and subgenre specific: "[h]is skill in dealing with horror; the beauty of his verse" (7). Instead of offering exemplary individuals 


\section{ELIZABETHAN LITERATURE.}

[This syllabus is divided by subjects and not by lectures. It is suggested that students should prepare themselves by reading some of the texts indicated. For reference and sup. plementary reading a bibliography is printed at the end of this syllabus.]

\section{I.-THE EARLIEST FORMS OF DRAMA.}

Popular festival and religious rite. The "liturgical" drama. The Guild plays. Difference between "miracle" plays, "moralities," and "interludes." Examination of several examples. Their peculiar charm and their essential dramatic qualities.

Read : *Everyman, Abraham and Isaac, and the Second Shepherds Play.

\section{II.-THE REVIVAL OF LEARNING.}

The Renaissance in England, and its effect upon the Drama. John Bale and Heywood. Influence of humanism not always beneficial. Study of Latin literature: Seneca and Plautus. Beginnings of blank verse. Development of set tragedy and comedy. Italian influence.

READ : Gorboduc or *Ralph Roister Doister.

\section{III.-THE ELIZABETHAN STAGE.}

Popularity of the Theatre. The theatres of Shakespeare's time: their construction, the audience, its character and its demands, the players and their life. The playwright: his task and his life. The continuous adaptation of old plays to current needs. Why Elizabethan life and thought found its most adequate expression in the theatre.

READ : The first chapters of ${ }^{*}$ G. P. Baker: Development of

Shakespeare as a Dramatist.

FIG. 1

The first page of Eliot's third-year syllabus for Modern English Literature, on Elizabethan literature. 
who are complete models of greatness, these post-Shakespearean playwrights are great as a collective effort toward the perfection of a particular form: "Each of the later dramatists has some unique quality, and in them English blank verse reaches its highest point" (7).

Coming in the final weeks of the three years that Eliot and his tutorial students spent together, this culminating vision of a set of unheralded playwrights whose value becomes apparent only when viewed as a collective takes on shades of the WEA's conviction that the value of tutorials becomes most apparent not in local records of individual papers submitted but in the context of the "common life" (Mansbridge 9). This ethos of extension education emerges as an explicitly literary value in The Sacred Wood, in which Eliot famously turns from great works to minor authors, whose uneven and collaborative work on existing literary forms enabled subsequent writers to continue the work of making literature.

\section{Southall in The Sacred Wood}

When Modern English Literature ended in the spring of 1919, Eliot's students gave him a copy of The Oxford Book of English Verse inscribed "with the gratitude and appreciation of the students of the Southall Tutorial Literature Class May 1919" (Eliot, Letters 353). Eliot spent the next several months transforming his lecture materials into book reviews, publishing thirteen reviews of criticism and scholarship on early modern literature by the spring of 1920. Six of these reviews would become essays in The Sacred Wood: "A Romantic Aristocrat," "'Rhetoric' and Poetic Drama," "Hamlet and His Problems," "Notes on the Blank Verse of Christopher Marlowe," "Ben Jonson," and "Philip Massinger." In other essays of The Sacred Wood, figures from the early modern syllabus-Marlowe, Thomas Elyot, Lyly, Webster, and Middleton-reappear.

Initial reviewers of The Sacred Wood were unaware of the extension classroom in which Eliot had most recently read this minor canon of poets and dramatists. To them, the essays' turn from major and beloved authors to more minor ones seemed elitist. They saw in Eliot's manner "the traces of a superior attitude" (Murry 194), "the coolness of the dandy and the air of a man of science" (" $\mathrm{S} a$ cred Wood" 733), the censoriousness of "the traditional Plymouth Brother" (Lynd 359), and "the detachment of the great surgeon" (Goldring 7). Eliot, they imagined, was setting an impossibly high critical standard. As one critic put it, "He assumes that art, in the sense of work of 'eternal intensity,' is something rare, exquisite, requiring intelligence for its apprehension, and indeed never understood save by a select minority" ("Sacred Wood" 733). And where early reviewers saw Eliot sequestering literature away in a laboratory, an exclusive heaven, or a surgical theater, modern-day critics have figured Eliot's beautiful prison as the classroom. Disciplinary historians like Guillory have suggested that Eliot's new canon gave birth to a specifically academic style of literary reading particularly associated with the classroom-a style of reading that attends exclusively to literary technique and form and forgets that literary texts were written in and about an everyday world (Cultural Capital 167-69).

But understanding Eliot's extension school teaching opens an entirely different reading of The Sacred Wood. That volume's characteristic gesture-its rejection of the major authors to which literary culture pays lip service and its appreciation of the subtler virtues of more workaday writers-draws on the WEA's attempts to revise authoritative, disciplinary knowledge by incorporating working-class history and experiences. When Eliot asserts, in those essays, that not all old literature is good literature-when in "The Perfect Critic" he faults Arnold for treating the masters of the past as "canonical literature" or in "Ben Jonson" describes Jonson as more admired than read-he refers almost 
directly to his own refusal to offer his busy students a mere "smattering" of culture with a reading list composed of long-admired major authors (xivn2, 95). Likewise, The Sacred Wood's appreciation of how historicism prepares past works for fresh judgment expresses lessons Eliot learned during the three-year transformation of his syllabi from an inert set of representative writers to an Elizabethan world of "living authors"; "We need an eye," Eliot writes in The Sacred Wood, "which can see the past in its place with its definite differences from the present, and yet so lively that it shall be as present to us as the present" (70). ${ }^{11}$

The minor canon of The Sacred Wood, like the literary world Eliot conjured in his classroom, relies on a communal vision of a literary past and future. This world is peopled not by great authors but by scholars, editors, readers, critics, and translators of variable abilities. The works that Eliot commends in The Sacred Wood are those written with no eye to posterity but rather for the immediate use of other writers in the tradition. The greatness of these works derives not from their enduring, transhistorical formal properties but from their connectivity. They represent an incremental improvement of literary forms borrowed from previous authors; the uneven quality of their work invites future writers to take up the pen to improve on them. In this way, Philip Massinger "prepared the way for Dryden," while in Dryden resides the last "living criticism" of Jonson (Eliot, Sacred Wood 123, 96). This principle of valuing works that allow for literary culture's continuation-a principle that informs, for example, Eliot's favoring of Dryden, through whom many lines flow, over "the Chinese Wall of Milton," after which blank verse suffers "retrogression" (78)-mirrors the WEA's rejection of individualized accreditation and its valuation of tutorials for the cultural formations they engendered.

The WEA's "highway" of education thus guided Eliot's creation of a genealogy of mi- nor poets who constitute the literary tradition. Eliot also borrowed from his tutorial a way of valuing the works of these minor figures. The seminar's circulation of the "simpler kind of facts about a work" from teacher to student as well as from student to teacher resurfaces in The Sacred Wood's treatment of information as necessary to literature's flourishing. Indeed, Eliot's rejection of the Romantics in The Sacred Wood stems from this principle. According to him, the Romantics "did not know enough"; their literary production "proceeded without having its proper data, without sufficient material to work with" $(9,10)$. Depending on the supremacy of individual genius, they worked without the aid of "second-order minds"-that is, without the help of those critics who were numerous and unburdened enough to "digest the heavy food of historical and scientific knowledge" through which the literary past becomes present and usable (69). The Sacred Wood is full of admiration for the paratextual apparatus of mediocre critics: the appendixes to George Cruikshank's essay on Massinger "are as valuable as the essay itself," Charles Whibley's introduction to Thomas Urquhart's Rabelais "contains all the irrelevant information about that writer which is what is wanted to stimulate a taste for him," and Professor Murray may be an awful translator of classical poetry but is thanked for bringing us "closer" to the classics through the medium of historical scholarship (112, 29, 68). Just as the Modern English Literature tutorial saw Eliot drawing on the kinds of information circulated by editors, scholars, and biographers and welcoming his students' fluency in bits of fact as preparatory to taste formation, so does The Sacred Wood recognize the value of the preparatory, informational work of criticism.

And just as Eliot's tutorial used bits of information to open up a vision of past authors as working writers, The Sacred Wood draws on historical and biographical information to call up the sociality of writing practices. Eliot 
describes Marlowe writing Dido "to order with the Aeneid in front of him" and imagines Jonson composing The Masques of Blackness in tandem with Inigo Jones designing its scenery (83). In his essay on Massinger, Eliot argues, "To understand Elizabethan drama it is necessary to study a dozen playwrights at once, to dissect with all care the complex growth, to ponder collaboration to the utmost line" (71). Using textual collation techniques to track revision practices, Eliot debunks myths of literary genius and the spontaneous creation of formally perfect works by revealing the incremental labor that goes into the creation of a poem or play. Examining examples of Marlowe's self-revision and his borrowing from Edmund Spenser, Eliot explains that, "somewhat contrary to usual opinion," Marlowe was not a genius but "a deliberate and conscious workman" (79). Indeed, when Eliot does esteem a Romantic-as in the case of William Blake-it is because textual scholars had dispelled Blake's self-mythologizing to reveal the conscious work of revision evident in his drafts: though "Blake believed much of his writing to be automatic," his manuscripts express that a "meticulous care in composition is everywhere apparent in the poems preserved in rough draft ... alteration on alteration, rearrangement after rearrangement, deletions, additions, and inversions" (138). This insistent emphasis threaded throughout The Sacred Wood, not just on writers as careful and meticulous craftspeople but on the everyday, laborious work of writing "to order" as "workmen" in groups, has its origins in Eliot's ad hoc attempt to enable the incremental work of his own students through reanimating the working practices and conditions of Elizabethan writers for them. Tracing this pedagogy into The Sacred Wood reveals how the momentary work of the classroom grows into a theory of literature.

In The Sacred Wood, of course, as in the Modern English Literature classroom, the gathering of information that reanimates the working lives of writers is not its own end; it is the preparation for critical judgment. Yet in neither book nor tutorial is critical judgment atemporal, objective, or fixed. The social life of the WEA seminar served for Eliot as an education in taste and the temporality of aesthetic judgment. In The Sacred Wood, these lessons reappear in Eliot's sense that certain books, such as Arthur Symons's The Symbolist Movement in Literature, are valuable in different ways at different moments of a life span. Reading Symons's criticism of the French symbolists before reading those poets themselves is an "introduction to wholly new feelings, as a revelation," even if after reading Paul Verlaine, Jules Laforgue, and Arthur Rimbaud one turns out to disagree with Symons's particular judgments. Symons's book may not, for any given reader, have "permanent value." Read once, it may be discarded or never reopened. And yet by raising the reader's interest and acting as an initial index to the symbolist poets, "it has led to results of permanent importance for him" (3). And additional life experience can reorient one's relationship to a major text. In the introduction to The Sacred Wood, Eliot explains that though "[t] he faults and foibles of Matthew Arnold are no less evident to me now than twelve years ago, after my first admiration for him; but I hope that now, on re-reading some of his prose with more care, I can better appreciate his position" (ix). Throughout The Sacred Wood remain traces of Eliot's early classroom's sense that the arc of one's life and one's momentary and changing circumstances necessarily and meaningfully shape valid critical judgments.

But above all, the Modern English Literature tutorial is present in The Sacred Wood's conviction that people make literary value. For Eliot, the call to transform canonical texts into the "living force" of literature is a necessarily social endeavor. Like the classroom in which this transformation began, Eliot's essays do not transmit a singular set of liter- 
ary values. Instead, they maintain a varied world in which thousands of small exchanges between writers and readers and among editors and teachers and students climb inside poems and plays; only later do these social exchanges come to seem to emanate from literary works themselves. In Eliot's extension school classroom we find the lived origins of what calcified into a received idea of the Eliotic canon. But by expanding our understanding of where literary study has actually happened to include classrooms like Eliot's, we can see how canons are made rather than merely received. In a contemporary moment in which literary study-and liberal arts more generally-threatens to become the exclusive property of elite and private universities, we need more than ever to build and preserve accounts of how classrooms at institutions of all kinds have discovered our core methods and made our critical classics. To see clearly what literary study is and where it can go, we must remember where it has been.

\section{NOTES}

1. A first wave of expansive disciplinary histories, beginning with Viswanathan's Masks of Conquest: Literary Study and British Rule in India, showed that the origins of English lay in colonial universities and other peripheral institutions. Because such studies traced the connections between literary education and state power, they focused on institutional records to draw conclusions about classroom practice. More recently, Renker's The Origins of American Literature Studies: An Institutional History considers literary study at Mount Holyoke College, Wilberforce University, and Ohio State University, as well as at Johns Hopkins University.

2. For a recent example of disciplinary history informed by reception history and focused on material practice, see Robson.

3. See McDowell 32-33. Matthews notes that Eliot dismissed such accounts of his outsized influence on literary study: "Eliot was assiduous, near the end of his life, in pointing out ... that he did not 'invent' the Early Modern period for the modern age, nor establish the accepted canon of its texts. But this has been the continuing belief of academic criticism" (6).
4. See Gilbert and Gubar; Brooker; and Lamos 17-54

5. See Guillory, "Ideology" 179, 185; Collini 16.

6. See also Styler. For a consideration of Eliot's teaching at Harvard in the early 1930s, see Bush. For full transcripts of Eliot's syllabi, see Schuchard, "T. S. Eliot."

7. Eagleton, in "The Rise of English," depicts extension school teaching as "distracting the masses from their immediate commitments" (23); Baldick, in The Social Mission of English Criticism, portrays extension lectures as bourgeois and dilettantish (76). See also Lawrie 5-6.

8. For a transcript of the parliamentary hearing that Burrows quotes, see Great Britain, Session Papers 150.

9. See Wellmon for an intellectual and cultural history of the interrelated goals of self-formation and knowledge production in the modern research university into which the extension school intervened.

10. The WEA's magazine, first published in 1910, was titled The Highway.

11. Gorak argues that The Sacred Wood aimed to "dismantle" Edwardian and Georgian notions of literary genius; he notes, "As an adult education lecturer, when Eliot considered how to present this important period to a non-academic audience, all he found were books by Edward Dowden, Walter Raleigh, and A. C. Swinburne that relayed the myth of genius to the untrained reader" (1064). Gorak contends that Eliot's engagement with minor poets and appreciation of nonexpressive elements of the writing process deepened in the years after The Sacred Wood, when Eliot became the prime reviewer of early modern scholarship for The Times Literary Supplement.

\section{Works Cited}

Atkinson, Mabel. "Syllabus of a Course of Tutorial Classes on the Social History of England." U of London P, 1911. Senate House Library, U of London, EM 6/6/5C.

Baldick, Chris. The Social Mission of English Criticism, 1848-1932. Clarendon Press / Oxford UP, 1983.

Bloor, R. H. U. "Syllabus of a Course of Lectures on Ideals and Issues of the Present Struggle." U of London P, 1917. Senate House Library, U of London, EM 6/6/5C

Brierley, S. S. "Syllabus for a Tutorial Class in Psychology." U of London P, 1917. Senate House Library, U of London, EM 6/6/5C.

Brooker, Jewel Spears. Mastery and Escape: T. S. Eliot and the Dialectic of Modernism. U of Massachusetts P, 1994.

Burrows, John H. University Adult Education in London: A Century of Achievement. U of London / National Institute of Adult Education, 1976.

Bush, Ron. “'Intensity by Association': T. S. Eliot's Passionate Allusions." Modernism/Modernity, vol. 20, no. 4, Nov. 2013, pp. 709-27.

Collini, Stefan. "From 'Non-fiction Prose' to 'Cultural Criticism': Genre and Disciplinarity in Victorian 
Studies." Rethinking Victorian Culture, edited by Juliet John and Alice Jenkins, Macmillan Press / St. Martin's Press, 1999, pp. 13-28.

Davies, Alice. "Syllabus of a Course of Tutorial Classes Some Writers of the Nineteenth Century and After." U of London P, 1913. Senate House Library, U of London, EM 6/6/5C.

Eagleton, Terry. "The Rise of English." Literary Theory: An Introduction, 2nd ed., U of Minnesota P, 1996.

Eliot, T. S. “The Function of Criticism." Selected Essays, 1917-1932, Faber and Faber, 1932, pp. 12-24.

- The Letters of T. S. Eliot, 1898-1922. Edited by Valerie Eliot and Hugh Haughton, rev. ed., Yale UP, 2011. Vol. 1 of The Letters of T. S. Eliot.

- The Sacred Wood: Essays on Poetry and Criticism. Alfred A. Knopf, 1921.

__. "Syllabus for a Course of Tutorial Classes on Modern English Literature.” U of London P, 1916. Senate House Library, U of London, EM 6/6/5.

. "Syllabus for a Course of Tutorial Classes on Modern English Literature (Second Year's Work).” U of London P, 1917. Senate House Library, U of London, EM 6/6/5.

__ . "Syllabus for a Course of Tutorial Classes on Modern English Literature (Third Year's Work).” U of London P, 1918. Senate House Library, U of London, EM 6/6/5.

Epstein, M. “Syllabus for a Course of Tutorial Classes on Descriptive Economics (Modern Society in Its Economic Aspect)." U of London P, 1912. Senate House Library, U of London, EM 6/6/5C.

. "Syllabus for a Course of Tutorial Classes on Descriptive Economics (Modern Society in Its Economic Aspect)." U of London P, 1915. Senate House Library, U of London, EM 6/6/5C.

. "Syllabus for a Course of Twenty Lectures (Modern Society in Its Economic Aspect)." U of London P, 1914. Senate House Library, U of London, EM 6/6/5C.

Farley, R. P. "Syllabus of a Course of Tutorial Classes on Poverty: Suggested Causes and Remedies (First Year's Work in Sociology)." U of London P, 1917-18. Senate House Library, U of London, EM 6/6/5C.

Freeman, Arnold. "Syllabus of a Tutorial Class on the Economic Problems of Demobilisation." U of London P, 1916. Senate House Library, U of London, EM 6/6/5C.

Gilbert, Sandra M., and Susan Gubar. No Man's Land: The Place of the Woman Writer in the Twentieth Century. Vol. 1, Yale UP, 1998.

Goldman, Lawrence. Dons and Workers: Oxford and Adult Education since 1850. Clarendon Press, 1995.

_. "The First Students in the Workers' Educational Association: Individual Enlightenment and Collective Advance." A Ministry of Enthusiasm: Centenary Essays on the Workers' Educational Association, edited by Stephen K. Roberts, Pluto Press, 2003, pp. 41-58.
Goldring, Douglas. "Modern Critical Prose." Chapbook, vol. 2, no. 8, Feb. 1920, pp. 7-14.

Gorak, Jan. "From Prodigality to Economy: T. S. Eliot on the 'Minor Elizabethans."' The Modern Language Review, vol. 108, no. 4, 2013, pp. 1064-85.

Great Britain, Parliament, House of Commons. Session Papers. Vol. 40, H. M. Stationery Office, 1913.

Guillory, John. Cultural Capital: The Problem of Literary Canon Formation. U of Chicago P, 1993.

. "The Ideology of Canon-Formation: T. S. Eliot and Cleanth Brooks." Critical Inquiry, vol. 10, no. 1, Sept. 1983, pp. 173-98.

Henderson, B. L. K. "Syllabus for a Tutorial Class in Aspects of Victorian Literature (First Year)." U of London P. Senate House Library, U of London, EM 6/6/5C.

Jack, A. A. "Lecturer's Report for the Life of the Nineteenth Century as Represented in Literature." University of London Joint Committee for the Promotion of the Higher Education of Working People Lecturers' and Examiners' Reports, session 1914-15, Summer 1914. Senate House Library, U of London, EM 2/23/74.

Lamos, Colleen. Deviant Modernism: Sexual and Textual Errancy in T. S. Eliot, James Joyce, and Marcel Proust. Cambridge UP, 1998.

Lawrie, Alexandra. The Beginnings of University English: Extramural Study, 1885-1910. Palgrave Macmillan, 2014.

Lynd, Robert. "Buried Alive.” Nation, 4 Dec. 1920, pp. 359-60.

Mansbridge, Albert. University Tutorial Classes: A Study in the Development of Higher Education among Working Men and Women. Longmans, Green, and Co., 1913.

Matthews, Steven. T. S. Eliot and Early Modern Literature. Oxford UP, 2013.

McDonald, Gail. Learning to Be Modern: Pound, Eliot, and the American University. Oxford UP, 1993.

McDowell, Nicholas. "Early Modern Stereotypes and the Rise of English: Jonson, Dryden, Arnold, Eliot.” Critical Quarterly, vol. 48, no. 3, Autumn 2006, pp. 25-34.

Murry, John Middleton. “The Sacred Wood." New Republic, 13 Apr. 1921, pp. 194-95.

Palmer, Mabel. "Syllabus for Problems of Social Economics Arising from the War." U of London P, 1916. Senate House Library, U of London, EM 6/6/5b.

Pringle, E. H. "Syllabus for Modern Economic Problems." U of London P, 1911. Senate House Library, U of London, EM 6/6/2.

Ransom, John Crowe. The New Criticism. New Directions, 1941.

Renker, Elizabeth. The Origins of American Literature Study: An Institutional History. Cambridge UP, 2010.

Robson, Catherine. Heart Beats: Everyday Life and the Memorized Poem. Princeton UP, 2012. 
Rose, Jonathan. The Intellectual Life of the British Working Classes. Yale UP, 2002.

“The Sacred Wood." New Statesman, 26 Mar. 1921, pp. 733-34.

Schuchard, Ronald. Eliot's Dark Angel: Intersections of Life and Art. Oxford UP, 1999.

. "T. S. Eliot as Extension Lecturer, 1916-1919." The Review of English Studies, vol. 25, no. 98, May 1974, pp. 163-73 / vol. 25, no. 99, Aug. 1974, pp. 292-304.

Shairp, Mordaunt. "Syllabus of a Course of Ten Lectures on the Literary Inspiration of the Great War." U of London P, 1919. Senate House Library, U of London, EM 6/6/5C.

Slater, Gilbert. "Syllabus of a Course of Tutorial Classes on the Worker and the State." U of London P, 1911. Senate House Library, U of London, EM 6/6/1.

Spurgeon, Caroline. "Lecturer's Report for Seminar on the Age of Johnson." Joint Committee for the Promotion of the Higher Education of Working People
Lecturers' and Examiners' Reports, session 1915-16. Senate House Library, U of London, EM 2/23/79.

Styler, W. E. "T. S. Eliot as Adult Tutor." Notes and Queries, vol. 19, no. 2, Feb. 1972, pp. 53-54.

Tayler, J. Lionel. "Syllabus for Course of Tutorial Classes on the Condition of the People," U of London P, 1911. Senate House Library, U of London EM 6/6/1.

. "Syllabus of a Preparatory Tutorial Class in Life in the Home (Some Human Domestic Life Problems)." U of London P, 1917. Senate House Library, U of London, EM 6/6/5C.

Tillyard, E. M. W. The Muse Unchained: An Intimate Account of the Revolution in English Studies at Cambridge. Bowes and Bowes, 1958.

Viswanathan, Gauri. Masks of Conquest: Literary Study and British Rule in India. Columbia UP, 1989.

Wellmon, Chad. Organizing Enlightenment: Information Overload and the Invention of the Modern Research University. Johns Hopkins UP, 2015. 